\title{
Promoting Financial and Cultural Citizenship Literacy as Mul- tiliteracy in Tourism Village
}

\author{
Universitas Negeri Semarang, Indonesia \\ *Email: arbarini.mint@mail.unnes.ac.id
}

Mintarsih Arbarini*, Tri Suminar, Liliek Desmawati

Submitted: 21 December 2020. Revised: 31 January 2021. Accepted: 13 February 2021

\begin{abstract}
Literacy skills provide opportunities to build society to face the global changes. This study aims to promoting the community members of the tourist village according to financial and cultural citizenship literacy as a part of multiliteracy in tourism village. This research applied descriptive qualitative approach. The subjects are 10 villagers in Jojogan Village, Wonosobo Regency. The method of data collecting use interview, observation, and documentation. Data analysis begins during the data collection process, performs data reduction, data presentation, and ends with drawing conclusions and verification. The findings describe promoting financial and cultural citizenship literacy as multiliteracy in Tourism Village is carried out in the community to have a financial and cultural literacy in their daily lives as a part of tourism village community. This activity promotes literacy cultur e by adjusting their free time because the learning schedule was coming from the community member's needs. With this condition, the manager and facilitator continuously try to adjust the conditions of the community members. These literacy learning activities include reading, writing, numerating, speaking, and listening. The benefit of this research is to provide an explanation that financial and cultural citizenship literacy as a part of multiliteracy in tourism village must be done.
\end{abstract}

Key words: Blended learning; Nonformal Education, Nonformal Education Unit

How to Cite: Arbarini, M., Suminar, T., \& Desmawati, L. (2021). Promoting Financial and Cultural Citizenship Literacy as Multiliteracy in Tourism Village. Journal of Nonformal Education, 7(1), 65-70.

DOI: http://dx.doi.org/10.15294/jne.v7i1.27874

\section{INTRODUCTION}

According to a report from the World Bank, Indonesia experienced economic growth in 2017, particularly $5.2 \%$. However, in reality, only a small part of the community who participates, so that economic and social disparities are widening. Based on the data results on the financial literacy index, in the Southeast Asian region, Indonesian people's financial literacy capacity is still low compared to Malaysia and Singapore (Fianto et al., 2017; Syaripudin, 2019).

On the other hand, the lack of public knowledge and financial literacy skills made a low utilization of banking and non-banking service products. Many people are trapped in using illegal financial services, and, apart from abundant natural resources, Indonesia is also rich in cultural values and local wisdom. Regarding values, concepts, and practices of life management, including managing finances. Apart from local wisdom, religious teachings also emphasize the need for education and financial management. On the one hand, a large amount of educational content in local wisdom and religious teachings is something to be proud of. The term literacy from UNESCO literacy is a continuum of learning that enables individuals to develop their knowledge and potential; pursue and achieve their goals, and participate fully in society (Arbarini, Jut- mini, Djoyoatmojo, \& Sutarno, 2016; Arbarini, Jutmini, Joyoatmojo, \& Sutarno, 2017)

Unfortunately, the understanding and application of local wisdom values and religious teachings have not been thoughtfully and intensively by the general public. From this point, the consumptive mindset and behavior tend to be less wise in prioritizing primary, secondary, and tertiary needs.

Indonesia is an archipelago country. Seventeen thousand more large and small islands stretch from Sabang to Merauke. Geographically, the islands in Indonesia separated by oceans and straits. The island's spread has made the Indonesian nation have various ethnic groups that also produce various languages, cultures, customs, habits, religions, and beliefs. It is not wrong if the Indonesian motto is Bhinneka Tunggal Ika, different but still one. (Hermiyanty, Wandira Ayu Bertin, 2017)

However, suppose every citizen who lives in the Unitary State of the Republic of Indonesia lacks awareness of the diversity of his nation. In that case, national stability could be destroyed. Without an awareness of diversity, interpersonal and inter-group conflicts will emerge without mutual respect and respect for different individuals and groups. Society will be easily divided by hatred and prejudice just because they do not know and understand their people's diversity.

Tourism is widely believed to be a panacea for economic development in several countries 
worldwide. Therefore tourism development is encouraged to stimulate the economy in these areas, particularly in developing countries. These countries can compete with and have a comparative advantage over many developed countries in terms of cultural heritage, traditional activities such as agriculture and handicrafts, nature, wildlife, climate, and the people's hospitality. Tourism can generate increased foreign exchange, growth in income, and employment for communities, which is often viewed as a benefit. (Husbands, 1989; Kuvan \& Akan, 2005; Lepp, 2007; Madrigal, 1993). However, the costs of tourism, such as social and environmental impacts, must always be weighed against the economic impacts (Haukeland, 1984; King, Pizam, \& Milman, 1993; Teo, 1994; Tsartas, 1992).

Based on the analysis of previous research findings, the main obstacle to rural residents' powerlessness is that the government has so far dominated literacy education through programs aimed at community members. The problems that arise in the implementation of multiliteracy is, literacy education that applied, are still limited to single literacy, namely reading, writing, and counting. As a result, residents of rural communities who are declared illiterate-free, who have not reached the literacy competency standard and have not taken advantage of their literacy after learning is complete tend to become illiterate again. Besides, the multiliterate education learning process has been oriented towards structured modules, not oriented towards the realities of learning needs. Facilitators still dominate learning yet lead to community participation to find and solve their problems.

\section{METHODS}

This research uses a qualitatitive method approach by promoting the community members of the tourist village accoding to financial and cultural citizenship literacy as a part of multiliteracy. The subjects are 10 villagers in Jojogan Village, Wonosobo Regency. The instrument using interview guides, observation, and documentation. The data collected by examining the data from interviews, observations, and documentation in a descriptive qualitative manner. Based on the primary data taken from the subjects by delivering multiliteration modules. Primary data collection use by taken directly from the subject. Data analysis begins during the data collection process, performs data reduction, data presentation, and ends with drawing conclusions and verification. This research conducted in March until August 2020.

\section{RESULT AND DISCUSSION}

\section{Factual Condition of Jojogan Village, Wonosobo Regency}

Jojogan Village is one of the tourist villages in Kejajar District with an altitude of 2,011 meters above sea level, located on the Dieng tourist route with a distance of $1 \mathrm{~km}$ from the Dieng Tourism Area. Jojogan Village has a potential economic tourism route and a potential tourism route in Wonosobo Regency. This Jojogan village has the tourism potential of Telaga Warna and Pengilon, which is managed by BKSDA as a source of economic growth for the village and the people.

Jojogan comes from the word njuju (Javanese), which means to stop by. Jojogan Village pledged itself to become an entrepreneurial village, where the village has a goal to alleviate poverty. Farming is the primary source of income. In 2012, many residents started doing tourism businesses so that in 2020, an increase in income from the tourism sector will positively impact the economy of the Jojogan Village community in general and can reduce the unemployment rate in Jojogan Village.

This is in line with research conducted by (Huttasin, 2008; Telfer, 2001) that tourism is believed to be a panacea for economic development in several countries globally; therefore, tourism development is encouraged to stimulate the economy in the region, especially in those developing countries. These countries are competitive and have comparative advantages over many developed countries in terms of cultural heritage, traditional activities such as agriculture and handicrafts, nature, wildlife, climate, and societal friendliness.

The manifestation of residents who initiated the existence of a tourist village is a crucial finding. This result is in line with the previous research findings that increased community participation in tourism is related to the belief that these activities follow the needs and abilities of local communities. It comes from the results of identifying residential fields so that this has more potential to get positive results, especially for cross-cultural interactions (Huttasin, 2008; Xie, 2010).

Promoting Financial and Cultural Citizenship Literacy as Multiliteracy in Tourism Village

Promoting Financial and Cultural Citizenship Literacy as Multiliteracy in Tourism Village is carried out in the community to have a financial and cultural literacy in their daily lives as a part of tourism village community. This activity promotes literacy culture by adjusting their free time because the learning schedule was coming from the community member's needs. Djibu (2019) stated that the facilitator needs to remind the community about the consistency of the 
various agreements that have been made previously. With this condition, the manager and facilitator continuously try to adjust the conditions of the community members.

The facilitator's role in multiliterate is different from that of teachers in formal schools because the conditions of adult citizens in society are different from students in schools. The facilitator's role is as a facilitator who helps and tries to make it easier for community members to learn. The facilitator as facilitator functions more as a learning resource. The facilitator's task begins with tracing the community's background, identifying the literacy skills of the community members in literacy competencies that consist of reading, writing, counting, listening, and speaking (Arbarini et al., 2016; Shofwan et al., 2019)

Thus, rural communities are expected to have several abilities that use as capital to develop their lives through independent business to obtain better economic, social, and cultural aspects. Besides, it is also necessary to estimate social and environmental impacts, always compared to economic impacts (Haukeland, 1984; King et al., 1993; Tsartas, 1992).

In general, these results are consistent where there are positive perceptions about the socio-cultural impact of tourism. Almost all respondents (99.6\%) agree or strongly agree that tourism has created jobs in their villages. More than $90 \%$ of the respondents agreed or strongly agreed with the statement that tourism provides women in the village with additional employment opportunities, reduces unemployment, increases the villagers' pride, increases family income, and improves living standards (Huttasin, 2008).

The results of interviews and observations of multiliterate facilitators obtained information such as 1) At the learning planning stage, the facilitator did not conduct a needs analysis as a prelude to compiling a lesson plan so that the learning plan did not refer to the needs of the community. 2) The determination of the material is very dependent on the facilitator. As a result, the learning material was not by the needs of the community. In formulating these literacy education learning objectives, literacy learning refers to the government's grid regarding multiliteracy. 3) Learning materials in literacy education include reading, writing, and arithmetic accompanied by functional skills. So far, learning materials still refer to materials from the government. They cannot make their learning materials according to the needs of the community. Moreover, 4) the facilitator carries out literacy, starting with learning, guiding community members, and learning the skills needed.

Planning, Implementing and Evaluating Financial and Cultural Citizenship Literacy as Multiliteracy in Tourism Village
The implementation of learning activities depends on the abilities and skills of the facilitators. At the implementation learning stages, learning activities begin with the preparation process by conducting socialization and providing information about the material to be studied. These literacy learning activities include reading, writing, arithmetic, speaking, and listening.

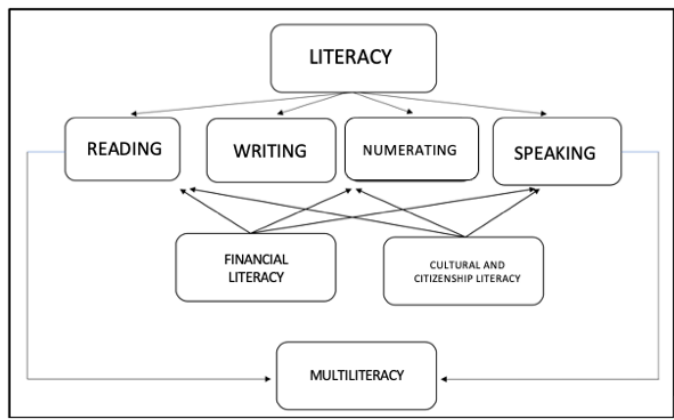

Figure 1. Framework of Financial Literacy and Cultural Citizenship Literacy as Multiliteracy

In reading literacy, learning activities go through the following stages: 1) The facilitator provides two stories and reading material related to economic problems and solutions in society and folk tales that contain cultural philosophies.2) Community members read stories. 3)The facilitator is assessing citizens' ability to read, especially the use of punctuation marks.

In writing literacy, learning activities through the following stages: 1) the facilitator asks community members to write down their daily expenses and the income they usually generate. Then the community was asked to make a description of the expenditure and income. Then the facilitator urges the community to write down cultural philosophies that emerge from the community and become the basis for behavior in the community and their meanings 2) the facilitator assesses the community's writing ability by assessing the results of their writing.

Moreover, for numeracy literacy learning through the following stages: 1) the facilitator makes arithmetic-related questions, using four arithmetic symbols (addition, subtraction, multiplication, and division) taken from cases related to financing and culture 2) questions made in the form of story questions, 3) the facilitator asks the community members to do this, 4) the facilitator assesses the numeracy ability of the community members.

The implementation of listening literacy learning activities through the following stages: 1) The facilitator prepares the reading. 2) The facilitator reads the discourse that is prepared. 3) The community listens to what the facilitator reads. 4) The facilitator asks community members about the content of the reading. 
5) Community members are retelling the content of the reading. 6) The facilitator assesses listening skills based on the ability to retell the content of the discourse read by the facilitator.

The implementation of speaking literacy learning is in the following stages: 1) The facilitator shows a picture of people in a bank or other (as an example in financial literacy) and a picture of local wisdom or local heroes (as an example in cultural literacy). 2) The facilitator asks the community about the messages contained in the picture. 3) The facilitator asks the community members to tell the message's contents in the picture shown. 4) The community, the community, tells the message's contents in the picture shown as requested by the facilitator. 5) The facilitator assesses the speaking ability of the community members through the ability to tell stories.

Literacies that are relevant and responsive to students may be engaging, but at times national and local curricula do not keep up with the changing technologies and multiple literacies present in students' communities and lives. Moreover, there are trends towards more scripted, standardization in literacy education (Crocco \& Costigan, 2007; Jerald, 2006).

The assessment of community literacy regarding listening, speaking, reading, writing, and arithmetic is described qualitatively. In determining and compiling assessment instruments, the facilitator determined all assessment instruments, starting from instruments and tools to assess community members' ability to write, read, listen, speak, and count. The assessment is carried out directly by the facilitator to the community members. The assessment is carried out in two stages, assessing and practicing community members' ability in literacy. The manager and facilitator directly motivate the community to keep up the spirit. Sometimes the manager and facilitator directly visit residents to homes for residents.

It is like defined components. The four multiliterate components include Practice, Explicit Instruction, Critical Framing, and Transformed Practice, talks about the essence of literacy and should be considered more broadly in scientific disciplines. The focus on the construct and examination of disciplinary knowledge (Critical Framing), in particular, is essential in terms of helping to articulate what is unique about thinking critically. (Julianda, Widiati, \& Djatmika, 2018; McPhee \& Pickren, 2017; Syaripudin, 2019).

Multiliteration implementation through the following steps: 1) Managers collect data on community members who have passed basic literacy or have a literacy certificate (sukma) and then adjust citizens' willingness to become community members at the advanced level of multiliterate. 2) Formulating the objectives of the literacy education program by coordinating with managers, facilitators, and community members. 3) The manager prepares a literacy education activity schedule - the implementation of literacy activities scheduled according to the study group's agreement. The schedule is arranged flexibly and adapts to the opportunities and learning readiness of community members and facilitators. A common constraint regarding schedule mapping is the level of attendance of community members. 4) The facilities used in the multiliterate process are still utilizing existing facilities. The place of activity for literacy education programs is the village hall, residents' houses, community reading gardens. 5) The manager carries out structuring the literacy education program manager by directly involving all parties.

Job descriptions of literacy education program administrators based on the program manager's structure and compiling a literacy curriculum format. Also, follow-up from the management by monitoring and motivating residents who have participated in learning to continue developing their abilities (Syaripudin, 2019). The assessment of literacy education programs in the community is carried out directly by the program manager in collaboration with other related parties. Alternatives to identity, authenticity, and community participation seen as a significant problem in ethnic tourism in China (Xie, 2010; Lew \& Wong, 2002, 2004; Ong, 1997; Tseng, 2002,)

Increased community participation in tourism may be related to the belief that these activities facilitate understanding between the diaspora and mainstream society and produce positive cross-cultural interactions. Therefore, it is crucial to understand how they view tourism developments and products for tourist consumption because the appearance of diasporic identities may differ among the stakeholders involved in the attraction. The success of the implementation and management of a unit of non-formal education is a reflection of the implementation of guidance on the performance continuously (Arbarini, Jutmini, Djoyoatmojo, \& Sutarno, 2016; Sutarto, Edi Mulyo, Shofwan, \& Siswanto, 2019).

\section{CONCLUSION}

The findings describe promoting financial and cultural citizenship literacy as multiliteracy in Tourism Village is carried out in the community to have a financial and cultural literacy in their daily lives as a part of tourism village community. This activity promotes literacy culture by adjusting their free time because the learning schedule was coming from the community member's needs. With this condition, the manager and facilitator continuously try to adjust the conditions of the community members. These literacy 
learning activities include reading, writing, arithmetic, speaking, and listening. The benefit of this research is to provide an explanation that financial and cultural citizenship literacy as a part of multiliteracy in tourism village must be done.

\section{REFERENCES}

Arbarini, M., Jutmini, S., Djoyoatmojo, S., \& Sutarno. (2016). Implementation of Functional Literacy Education by Participatory Learning as Effort of Lifelong Learning. Proceeding of the International Conference on Teacher Training and Education, 2(1), 734-745.

Arbarini, M., Jutmini, S., Joyoatmojo, S., \& Sutarno. (2017). Participatory Learning Model on Adults Literacy Education of Rural Communities. International Journal of Education, Psychology and Counseling, 2(6), 153-164.

Crocco, M. S., \& Costigan, A. T. (2007). The Narrowing of Curriculum and Pedagogy Urban Educators Speak Out. Urban Education, 512-535.

Djibu, R., Shofwan, I., \& Umanailo, M. C. B. (2019). Development of andragogical learning model to improve life skill for teenagers who drop out of school in Gorontalo city. International Journal of Scientific and Technology Research, 8(11), 25342542.

Fianto, F., Prismayani, R., Wijaya, N. I., Miftahussururi, Hanifah, N., Nento, M. N., ... Adryansyah, N. (2017). Gerakan Literasi Finansial. 1-32.

Haukeland, J. V. (1984). Sociocultural impacts of tourism in Scandinavia. Studies of three host communities. Tourism Management, 5(3), 207214.

Hermiyanty, Wandira Ayu Bertin, D. S. (2017). Literasi Budaya dan Kewargaan. Gerakan Literasi Nasional, 8(9), 1-58.

Husbands, W. (1989). Social status and perception of tourism in Zambia. Annals of Tourism Research, 16(2), 237-253.

Huttasin, N. (2008). Perceived social impacts of tourism by residents in the OTOP tourism village, Thailand. Asia Pacific Journal of Tourism Research, 13(2), 175-191.

Jerald, C. D. (2006). The Hidden Costs of Curriculum Narrowing. Issue Brief. 6. Retrieved from http://search.proquest.com/docview/62108753?acc ountid $=14744$

Julianda, Widiati, U., \& Djatmika, E. T. (2018). Pengaruh Strategi Pembelajaran Inkuiri Berbasis Keterampilan Multiliterasi terhadap Kemampuan Berpikir Kritis Siswa. Jurnal Pendidikan: Teori, Penelitian, Dan Pengembangan, (2012), 460-467.
King, B., Pizam, A., \& Milman, A. (1993). Social impacts of tourism. Annals of Tourism Research, 20(4), 650-665.

Kuvan, Y., \& Akan, P. (2005). Residents' attitudes toward general and forest-related impacts of tourism: The case of Belek, Antalya. Tourism Management, 26(5), 691-706.

Lepp, A. (2007). Residents' attitudes towards tourism in Bigodi village, Uganda. Tourism Management, 28(3), 876-885.

Lew, A.\&Wong, A. (2002). Tourism and the Chinese dia- spora. In C. M. Hall \&A. Williams (Eds.), Tourism and migration: New relationships between production and consumption (pp. 205-220). Dordrecht, The Nether- land: Kluwer Academic.

Lew, A. \& Wong, A. (2004). Sojourners, guanxi and clan associations: Social capital and overseas Chinese tourism to china. In T. Cole \& D. Timothy (Eds), Tourism, diasporas and space (pp. 202214). London: Routledge.

Madrigal, R. (1993). A tale of tourism in two cities. Annals of Tourism Research, 20(2), 336-353.

McPhee, S., \& Pickren, G. (2017). Blended learning with international students: a multiliteracies approach. Journal of Geography in Higher Education, 41(3), 418-433.

Ong, A. (1997). Chinese transnationalism as an alternative modernity. In A. Ong \&D. Nonini (Eds.), Ungrounded empires: The cultural politics ofmodern Chinese trans- nationalism (pp. 3-36). New York: Routledge.

Shofwan, I., Raharjo, T. J., Achmad Rifai, R. C., Fakhruddin, F., Sutarto, J., Utsman, U., ... Umanailo, M. C. B. (2019). Non-formal learning strategy based on tahfidz and character in the primary school. International Journal of Scientific and Technology Research, 8(10), 1987-1992.

Sutarto, J., Edi Mulyo, S., Shofwan, I., \& Siswanto, Y. (2019). The Impact of E-Training Model on the Improvement of Professional Competence of PAUD-DIKMAS Educators. KnE Social Sciences, 2019, 290-300.

Syaripudin, T. (2019). Multiliteration and Higher Order Thinking Skills Implications to Education. International Journal of Science and Applied Science: Conference Series, 3(1), 131.

Telfer, D. J. (2001). From a Wine Tourism Village to a Regional Wine Route: An Investigation of the Competitive Advantage of Embedded Clusters in Niagara, Canada. Tourism Recreation Research, 26(2), 23-33.

Teo, P. (1994). Assessing socio-cultural impacts: the case of Singapore. Tourism Management, 15(2), 126-136.

Tsartas, P. (1992). Impacts of Socioeconomic. 19(1), 516-533. 
Mintarsih Arbarini et al. / Journal of Nonformal Education 7 (1) (2021): 65-70

Tseng, Y. F. (2002). From "us" to "them": Diasporic linkages and identity politics. Identities: Global Studies in Culture and Power, 9, 383-404.
Xie, P. F. (2010). Developing ethnic tourism in a diaspora community: The indonesian village on Hainan Island, China. Asia Pacific Journal of Tourism Research, 15(3), 367-382. 